\title{
Study on Economic Activity Analysis based on the Interaction of "Operation, Value and Performance"
}

\author{
Jie $\mathrm{GaO}^{1, *}$ \\ ${ }^{1}$ State Grid Shanghai Municipal Electric Power Company, Internet Department, 1122, YUANSHEN Rd. SHANGHAI, CHINA
}

\begin{abstract}
In order to meet external regulation and challenges, and improve the quality of internal economic activity analysis, this study establishes a linkage analysis system from corporate strategy to strategic objectives to financial indicators to business indicators by building 3 independent and interrelated analysis models. One of them is the model of influencing factors of change of operating efficiency index, one of them is the traceability analysis model of the sales of electricity and electricity price, and the last one is an investment performance traceability analysis model. In this study, the actual data of a unit is used as an example. With the help of big data analysis, we fully tap the value of the company's big data, accurately locate the weak links and risk points of management. By doing this we finely promote economic activity analysis system more comprehensive, more real-time, more dynamic and more intelligent, and thus improve the efficiency of business decision-making. The practicality of economic activity analysis based on "operation, value and performance" is confirmed.
\end{abstract}

\section{Background}

Affected by the increasing downward pressure on macro-economy and the continuing economic and trade frictions between China and the United States, the growth rate of the company's electricity sales has decreased significantly, and the incremental benefits of electricity growth have further narrowed. In 2019, the general industrial and commercial price again reduced, and the adjustment of the implementation mode of twopart electricity price have had a negative impact on corporate revenues, and other policy factors in 2020, such as the state to further promote the reduction of manufacturing costs of electricity, and all the liberalization of industrial enterprises above the scale to participate in electricity market-oriented transactions, will continue to have a profit-making impact. the uncertainty and instability in the operation of the company has obviously increased. It is necessary to stabilize the business situation by looking inward and digging potential efficiency. The company's "three-type two-network, world-class" new era strategic objectives require further cost reduction and cost savings, and strengthen "precision input, lean management and fine operation", further improve the efficiency of resource allocation, and finally promote the power grid and the company to achieve high-quality development.

In this context, the company's current economic activity analysis is still based on a single indicator analysis, lacking of index-to-index causality analysis and linkage analysis. It is difficult to trace from performance results to business drivers, which limiting the improvement of management lean. How to make full use of the big data of the company's industry and wealth to improve the quality of economic activity analysis, and promote the systematic, comprehensive, real-time, dynamic and intelligent analysis of economic activities, and optimise the efficiency of business decision-making, is an important topic of economic activity analysis.

\section{Research ideas}

This study is driven by strategic indicators that reflect operating results and operating quality as the core. It analyzes the analysis of business activities by analysing the motivational value indicators of asset operation efficiency, business strategy, and planning goals, and using the motivational value indicators as entry points. Tap the inherent characteristics of the company's economic operations to serve the company's operating decisions. Specific research ideas see Figure 1.

\footnotetext{
* Corresponding author: gaoj@sh.sgcc.com.cn
} 


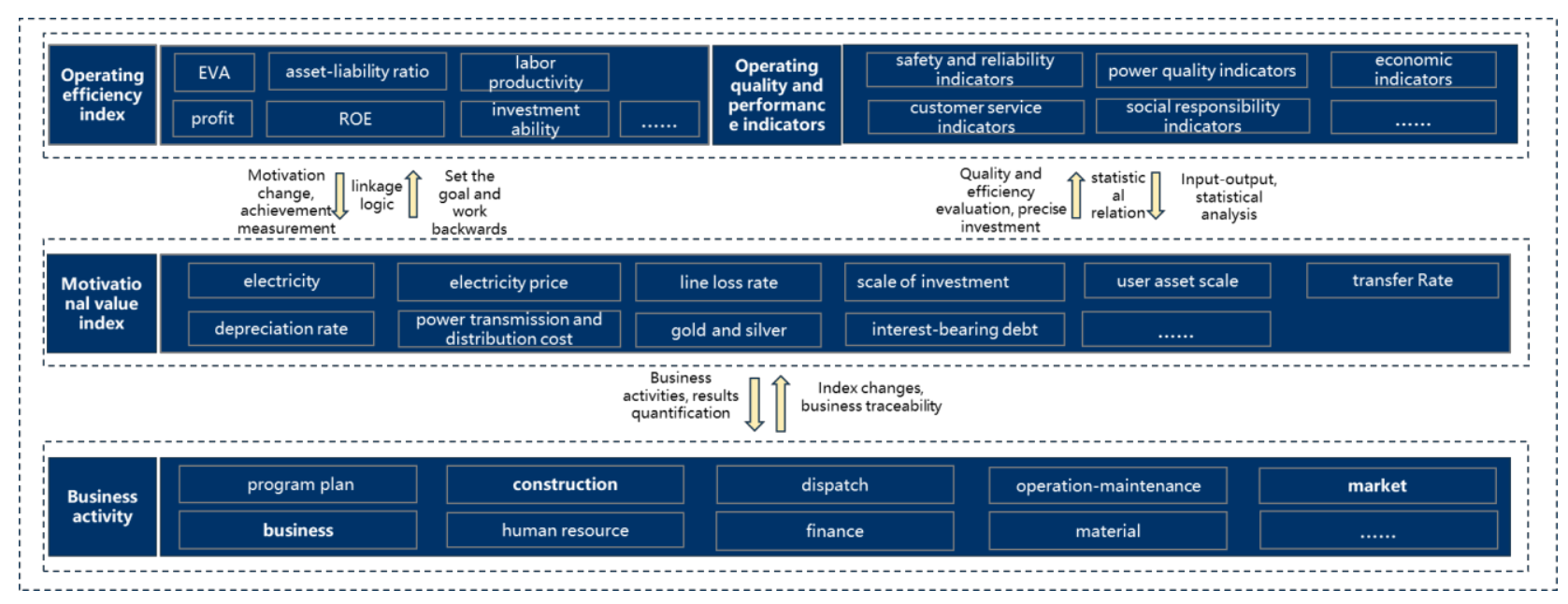

Figure 1 Research ideas of Economic Activity Analysis based on the interaction of "Operation, Value and Performance"

\section{Specific methods}

This study improves and deepens the analysis of the company's economic activities by constructing 3 models, including an analysis model of the influencing factors of change of operating efficiency index, a traceability analysis model of the sales of electricity and electricity price, and an investment performance traceability analysis model. Among them, the analysis model of the influencing factors of change of operating efficiency index supports the company to dismantle the profitbased operating efficiency index change sour to electricity, electricity price and other basic motivational value index layer. The other 2 models further support the company to trace the motivational value indicator to the specific business activity layer, and thus building a " Operating efficiency index layer - Motivational value index layer - business activity layer" economic activity analysis system of vertical business-financial integration.

\subsection{Analysis model of the influencing factors of change of operating efficiency index}

With profit as the core, the income and cost factors are broken down layer by layer. The income side is mainly based on electricity sales and electricity prices. Among them, the changes in electricity sales are compared and analyzed in terms of increasing supply and sales, power outage losses, and progress of new load projects. The changes in electricity price are compared and analyzed in terms of market-based transactions and incremental distribution networks. The cost side is dominated by the cost of transmission and distribution, which was broken down according to the nature of the cost into depreciation and operation maintenance costs. Taking project cost as the grasping point, we mainly analyze the new asset depreciation brought about by capital investment, transfer capital and depreciation rate, and analyze operation maintenance costs change resulting from cost investment and budget completions. Both capital investment and cost investment projects are refined according to the type of project and investment direction.
Capital investment includes Infrastructure Investment (such as Power Grid Infrastructure Investment, Industry Infrastructure Investment, Smallscale Infrastructure Investment), Technological Transformation Investment (such as Production Technological Transformation Investment, Production assistance Technological Transformation Investment, Industry Technological Transformation Investment), Fixed Asset Retail Purchase Investment, Marketing Investment (capitalization), Information Investment (capitalization). Infrastructure Investment is classified by Policy Investment and Non-policy Investment, Policy Investment is classified by large-scale Power Protection Project Investment, Village Supporting Agricultural Network Investment and so on. Non-policy investment is classified by UHV Project Investment, 750-220kV Main Network Project Investment, $110 \mathrm{kV}$ and the following Urban Network Engineering Investment - Ubiquitous Electricity Internet of Things and so on. Production Technological Transformation Investment is classified by the Power Grid Equipment Safety Input, World-class City Distribution Network Transformation Investment, Major Event Protection Investment and so on; Fixed Asset Retail Purchase Investment is classified by the Power Grid and the Company's Safety Input, Production and Management Tools, Instruments Acquisition and so on.; Marketing Investment (capitalization) is classified by Special Input for Metering Devices, Construction of Electric Vehicle Charge-changing Facilities and so on. Information Investment (capitalization) is classified by the State Grid's Cloud Platform and other key information projects.

Cost Investment includes Overhaul Investment (such as Production Overhaul Investment, Production Assistance Overhaul Investment, Industry Overhaul Investment, Marketing Investment (cost), Informatization Investment (cost), Research and Development Investment, Management Consulting, Education and Training Investment. Production Overhaul Investment is classified by the Power Grid Equipment Safety Input, the Major Event Protection Investment and other directions. The direction of Marketing and Informatization Investment (cost) is 
the same as Marketing and Informatization Investment (capitalization). Research and Development Investment is classified by National Supporting Funds

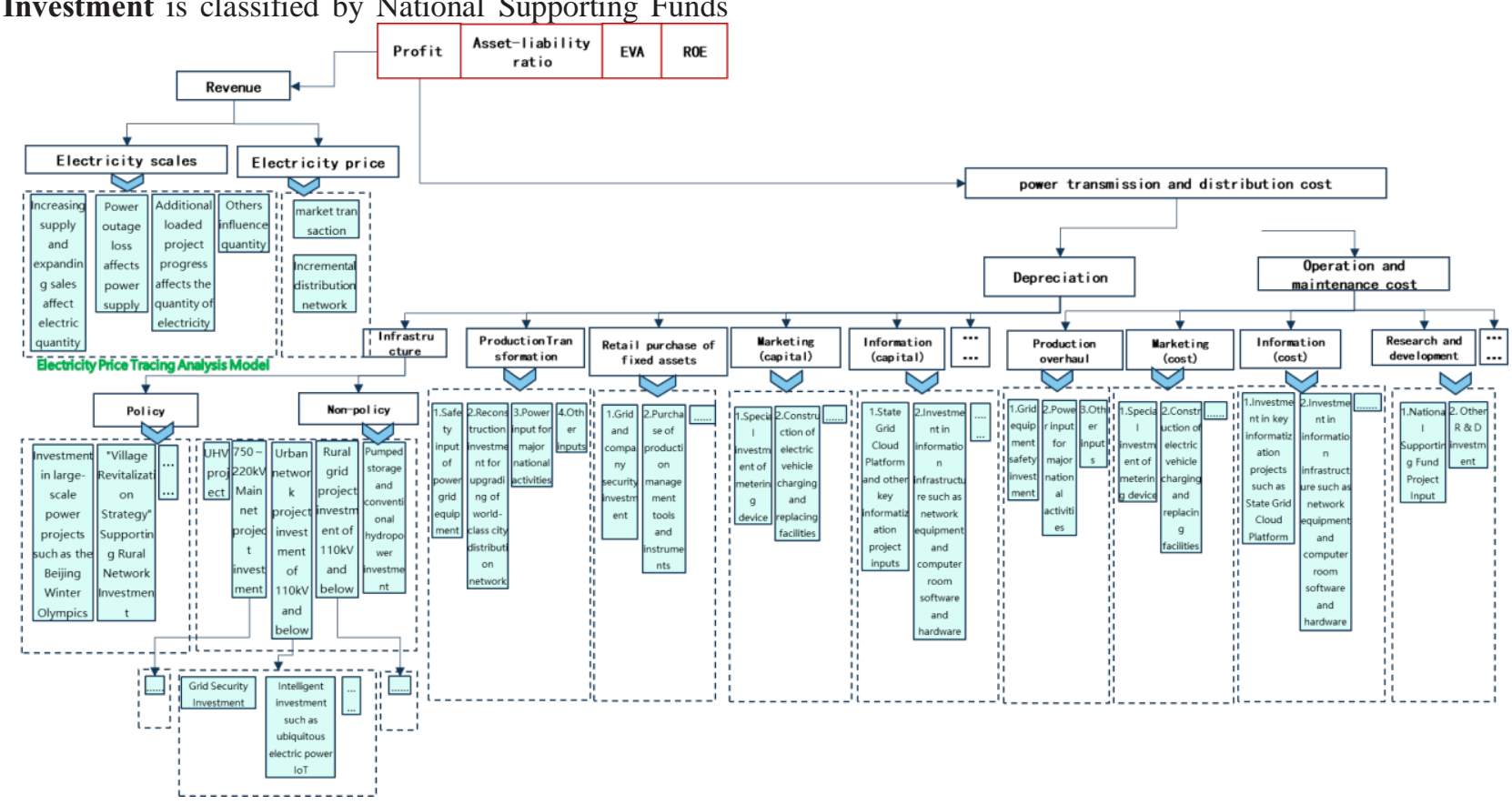

Figure 2 Framework of analysis model of the influencing factors of change of operating efficiency index

By analyzing the impact of various factors on revenue and cost, and analyzing the impact of year-onyear differences on revenue and cost, this paper thereby revealing the main business drivers and weak points of management of profit differences, and consolidating value creation capabilities.

\subsection{Traceability analysis model of the sales of electricity and electricity price}

\subsubsection{Main business factors of electricity and electricity price changes}

On the basis of the analysis model of the influence factors of the change of operating efficiency index, this paper conducts quantitative calculation and analysis of the business activities factors of electricity and electricity price changes, mining factors affecting the changes in electricity and electricity prices from the aspects such as the Increased Supply and Distribution, Power Failure Losses, N ew L oad Type Project Progress, $M$ arket-oriented Trading Methods, Incremental Distribution Network and so on.

A mong the 4 categories of business activities related to electricity changes, Increased Supply and Distribution mainly affected by $\mathrm{New}$ Capacity in High/L ow-Pressure User Industry Expansion, A verage L ength of High/L ow Pressure U ser Industry Expansion, Power Substitution and other business indicators. Power Failure Losses is affected by business indicators such as Equipment Planning Repair Loss of Power, Equipment Failure Repair Loss of Power and other business indicators. New Load Type Project Progress is affected by the Planned Delivery Rate of the Substation
Project Investment and other directions. Detailed in Figure 2.
Supporting Delivery Project, other such as Distributed Clean Energy Self-use and Demand Side Response Reduces Power Supply, and other factors will also have an impact on the size of the electricity sales.

The main motivations for operational activities related to electricity price changes are the $M$ arket-based Transaction Power Share and Incremental Power Distribution Network Sales.

\subsubsection{The way business factors affect electricity and electricity price}

By sorting out the specific ways and methods of the impact of various business indicators on electricity and electricity price, this paper constructs a traceability analysis model of the sales of electricity and electricity price based on business indicators, such as New Capacity, Average Load, Production Shift Hours, Quarterly Calendar Days, Scheduled Overhaul Duration, $M$ arket-based Transaction Power Share and so on. Changes in electricity and electricity prices are transmitted to changes in income, and then to changes in other economic benefit indexes, thus achieving the quantitative analysis of economic benefits under the perspective of business motivation. Specific ways of quantifying see Table 1. 
Table1. The methods of quantifying the main business indicators.

\begin{tabular}{|c|c|c|c|c|}
\hline $\begin{array}{c}\text { Driver } \\
\text { Value } \\
\text { Indicator }\end{array}$ & & Business Indicator & $\begin{array}{l}\text { Relationship } \\
\text { with profit }\end{array}$ & way to quantify \\
\hline \multirow{10}{*}{$\begin{array}{l}\text { sales of } \\
\text { electricity }\end{array}$} & \multirow{5}{*}{$\begin{array}{l}\text { increased } \\
\text { supply and } \\
\text { distribution }\end{array}$} & $\begin{array}{l}\text { new capacity in high-pressure user } \\
\text { industry expansion }\end{array}$ & + & $\begin{array}{c}\text { electricity sales = expansion of high-voltage } \\
\text { installed capacity * average load * production } \\
\text { shift hours * quarterly calendar days }\end{array}$ \\
\hline & & $\begin{array}{c}\text { new capacity in low-pressure user } \\
\text { industry expansion }\end{array}$ & + & $\begin{array}{c}\text { electricity sales }=\text { expansion of low-voltage } \\
\text { installed capacity * average load * production } \\
\text { shift hours * quarterly calendar days }\end{array}$ \\
\hline & & $\begin{array}{l}\text { average length of high-pressure } \\
\text { user industry expansion }\end{array}$ & - & $\begin{array}{l}\text { electricity sales }=\text { average time for high- } \\
\text { pressure user industry expansion } * \text { average } \\
\text { installed capacity * production shift hours }\end{array}$ \\
\hline & & $\begin{array}{l}\text { average time for low-pressure user } \\
\text { industry expansion }\end{array}$ & - & $\begin{array}{c}\text { electricity sales }=\text { average time for low-pressure } \\
\text { user industry expansion * average installed } \\
\text { capacity * production shift hours }\end{array}$ \\
\hline & & power substitute & + & electricity sales $=$ Power substitute \\
\hline & \multirow{2}{*}{$\begin{array}{l}\text { power failure } \\
\text { losses }\end{array}$} & $\begin{array}{c}\text { equipment planning repair loss of } \\
\text { power }\end{array}$ & - & $\begin{array}{c}\text { electricity sales = approximate daily average } \\
\text { load } * \text { scheduled overhaul duration }\end{array}$ \\
\hline & & $\begin{array}{l}\text { equipment failure repair loss of } \\
\text { power }\end{array}$ & - & $\begin{array}{l}\text { electricity sales = approximate daily average } \\
\text { load } * \text { (arrival time }+ \text { repair time })\end{array}$ \\
\hline & $\begin{array}{l}\text { new load } \\
\text { type project } \\
\text { progress }\end{array}$ & $\begin{array}{l}\text { the planned delivery rate of the } \\
\text { substation supporting delivery } \\
\text { project }\end{array}$ & + & $\begin{array}{l}\text { electricity sales }=\text { average daily electricity sales } \\
\text { after the project is put into operation } * \text { days } \\
\text { ahead of schedule (put into operation on the } \\
\text { same year) } \\
=\text { daily return on unit investment } * \sum \text { (investment } \\
\text { amount } * \text { days ahead of schedule ) (put into } \\
\text { operation on next year) }\end{array}$ \\
\hline & \multirow{2}{*}{ Other } & distributed clean energy self-use & - & $\begin{array}{c}\text { electricity sales }=\text { distributed clean energy self- } \\
\text { use }\end{array}$ \\
\hline & & $\begin{array}{l}\text { demand side response reduces } \\
\text { power supply }\end{array}$ & - & $\begin{array}{c}\text { electricity sales = demand side response reduces } \\
\text { power supply }\end{array}$ \\
\hline \multirow[t]{2}{*}{$\begin{array}{l}\text { Electricity } \\
\text { price }\end{array}$} & \multicolumn{2}{|c|}{ market-based transaction power share } & - & $\begin{array}{l}\text { electricity price }=[\text { market-based transaction } \\
\text { power share } * \text { electricity sales } * \text { transmission } \\
\text { and distribution price }+(1-\text { market-based } \\
\text { transaction power share }) * \text { electricity sales } * \\
\text { purchase price difference }] / \text { electricity sales }\end{array}$ \\
\hline & \multicolumn{2}{|c|}{ incremental power distribution network sales } & - & $\begin{array}{c}\text { electricity price }=\text { Incremental power } \\
\text { distribution network sales * distribution price of } \\
\text { this voltage level / electricity sales }\end{array}$ \\
\hline
\end{tabular}

The study starts with the basic data statistics such as quarter market-based electricity sales and non- market-based electricity sales ,new capacity, average load, production shift hours, quarterly calendar days, scheduled overhaul duration, market-based transaction power share and other business basic data. Using the quantifying relationships described in table 1 to measure the amount of electricity and electricity price changes under each business indicators. Based on the relationships between electricity, electricity price and income, we further quantify the impact on the gross margin sold.

\subsection{Investment performance traceability analysis model}

About $90 \%$ of the investment expenditure of Power Grid companies is carried by projects, and the abnormal implementation of the project investment will inevitably lead to fluctuations in the cost of transmission and distribution. Cost Investment projects affect costs through the progress of investment budget execution, and capital Investment projects affect costs through the execution of capital transfers and depreciation.

By refining cost and capital investments in Analysis model of the influencing factors of change of operating efficiency index to each specific project, and tracing the abnormal points of the project's investment performance, we pinpoint the problem links of problem projects, and then promote the rectification of problems and the normalization of investment execution.This paper takes the budget execution progress as the starting point of analyzing cost investment projects, and diagnoses the problem project from the perspective of sub-project, sub-voltage level, and sub-management level. We take the abnormal capital transfer rate as the entry point of analyzing capital investment projects, and reverse trace the problem project investment implementation of the key link in the key indicators. Diagnosis and analysis of problem projects are carried out from the perspective of the implementation progress of its investment budget and compliance and rationality. The following takes the construction of a capital investment performance analysis index system as an example to illustrate the construction of a source performance analysis model for investment performance.

\subsubsection{Budget execution progress analysis indicator system}

Starting from the whole process of project construction, this paper focuses on the key risk points of key links, sorts out the investment budget execution progress indicators and timeliness judgment criteria, and then constructs an investment budget execution progress analysis indicator system. See Table 2 for details. 
Table2. Budget execution progress analysis indicator system.

\begin{tabular}{|c|c|c|}
\hline Process & Investment budget implementation progress & Timeliness of investment budget execution \\
\hline $\begin{array}{l}\text { Plan, budget } \\
\text { release }\end{array}$ & $\begin{array}{l}\text { investment plans, investment budgets, whether there } \\
\text { have been significant changes in the design and the } \\
\text { amount of the investment changes }\end{array}$ & - \\
\hline $\begin{array}{l}\text { Demand } \\
\text { presentation }\end{array}$ & amount of demand reporting, demand report rate & Whether the demand is timely \\
\hline Bid & Tender amount, tender rate & Is the tender presentation timely? \\
\hline $\begin{array}{l}\text { Contract } \\
\text { signing }\end{array}$ & Contract signing amount, contract signing rate & Is the contract signed in a timely manner? \\
\hline Project starts & - & Whether to start work in time \\
\hline $\begin{array}{l}\text { Construction of } \\
\text { the project }\end{array}$ & $\begin{array}{l}\text { Cumulative cost accounting, cumulative cost recording } \\
\text { progress, cumulative investment completion, } \\
\text { investment plan completion rate }\end{array}$ & - \\
\hline $\begin{array}{l}\text { Completed and } \\
\text { put into } \\
\text { operation }\end{array}$ & Budget balance rate & $\begin{array}{l}\text { Whether to put into production, whether to put into } \\
\text { production in time }\end{array}$ \\
\hline $\begin{array}{l}\text { Transfer of } \\
\text { capital }\end{array}$ & Investment plan transfer rate & \\
\hline Project close & _ & Whether to close in ERP in time \\
\hline
\end{tabular}

\subsubsection{Compliance \& rationality analysis index system construction}

Starting from the entire process of project construction, this article aims to reflect the authenticity of project investment execution and compliance and reasonableness, and develops an indicator system design in accordance with the key risk points of key business throughout the project construction. As detailed in table 3.

Table3. Budget execution compliance \& rationality analysis index system construction.

\begin{tabular}{|c|c|c|}
\hline Process & $\begin{array}{c}\text { Clear implementation of } \\
\text { standard indicators }\end{array}$ & Statistical metrics based on business rules \\
\hline $\begin{array}{l}\text { ERP construction } \\
\text { project }\end{array}$ & - & Whether there is a match between planning, ERP and PMS systems \\
\hline Project starts & - & Whether to start according to the milestone plan, ahead of the curve or lag start \\
\hline Material stake & - & $\begin{array}{l}\text { Whether the time of material receiving matches the construction progress, whether the } \\
\text { proportion of the amount of material receiving, and the scale of the material is } \\
\text { abnormal. }\end{array}$ \\
\hline $\begin{array}{l}\text { Construction of the } \\
\text { project }\end{array}$ & . & $\begin{array}{l}\text { Start-up stops, Downtime for more than } 3 \text { months, Over-phase project, Whether there is } \\
\text { an investment plan risk warning, Investment plan completion risk, Fourth quarter tail, } \\
\text { Construction and financial and investment progress deviation warning }\end{array}$ \\
\hline $\begin{array}{l}\text { Completed and put } \\
\text { into operation }\end{array}$ & & $\begin{array}{l}\text { Check the authenticity of production with PMS / Electricity acquisition system, } \\
\text { Consistent with the scale of the key materials and the scale of equipment ledger } \\
\text { collection }\end{array}$ \\
\hline Material withdrawal & - & Whether there is a single write-off of material spooling \\
\hline Project settlement & $\begin{array}{l}\text { Whether the settlement time } \\
\text { exceeds the specified time limit }\end{array}$ & Whether the actual settlement time lags behind the planned settlement time \\
\hline $\begin{array}{l}\text { Final accounts for } \\
\text { completion }\end{array}$ & $\begin{array}{l}\text { Whether the closing time } \\
\text { exceeds the specified time limit }\end{array}$ & $\bar{L}$ \\
\hline Transfer of capital & $\begin{array}{l}\text { Whether the transfer time } \\
\text { exceeds the specified time limit }\end{array}$ & Transfer rate \\
\hline ERP project closure & $\begin{array}{l}\text { Whether the project is closed } \\
\text { later than the specified time limit }\end{array}$ & Whether ERP is off or not, whether to reopen in ERP \\
\hline
\end{tabular}

\subsection{Model application}

This article takes a certain unit as an example, and applies the model to analyze the influencing factors of changes in operating efficiency indicators and traceability analysis of business reasons. The results are as shown in Figure 3. 


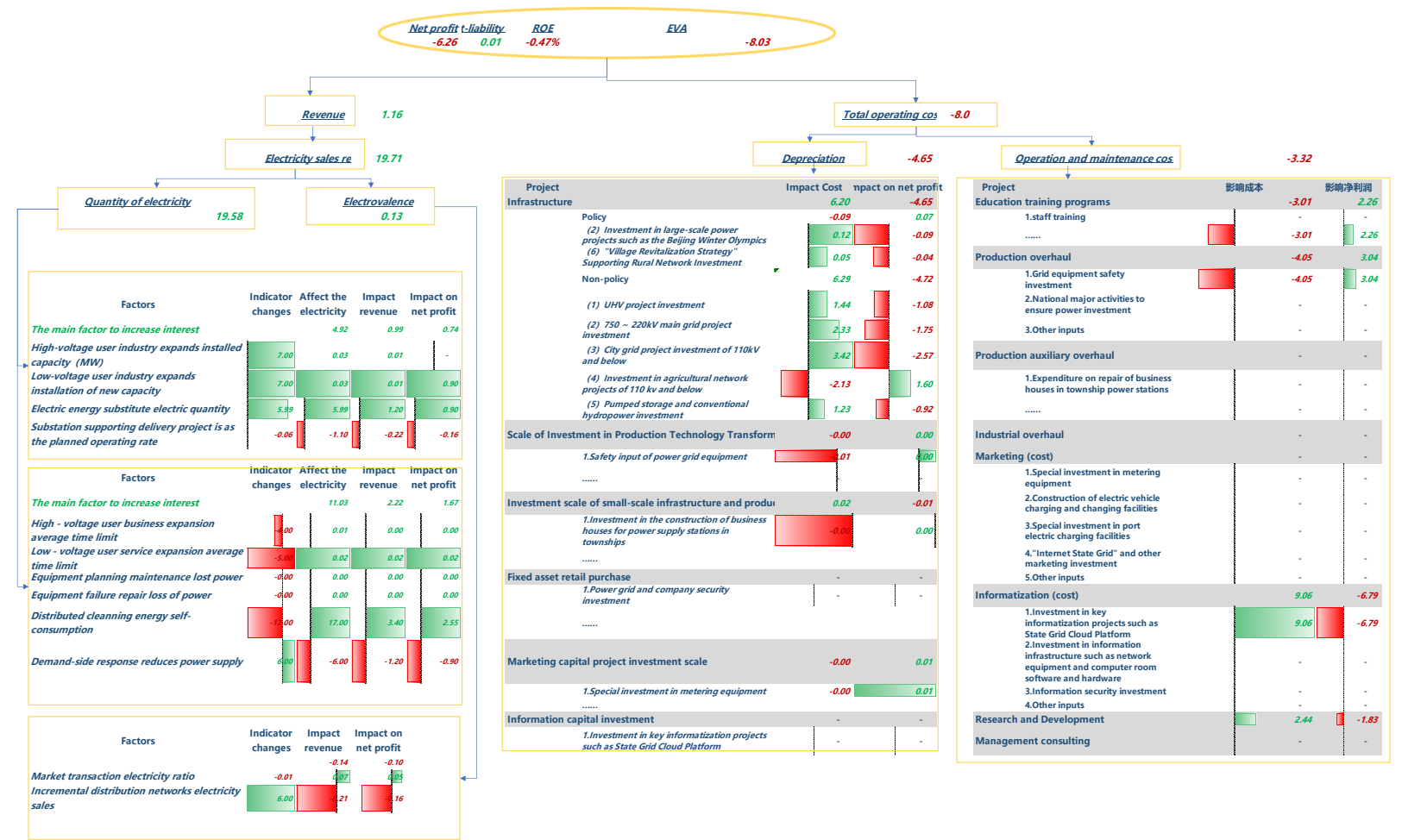

Figure 3 Example of an analysis of the influencing factors of change of a company's operating efficiency index

Net profit Year-on-year decrease was mainly due to a significant increase in transmission and distribution costs, which offset the increase in the growth of electricity sales.

The growth in electricity sales revenue was mainly due to the rapid growth of electricity sales, and the rapid growth of electricity sales was due to the rapid growth of new capacity in low-pressure user industry expansion and power substitute and the shortening of the average time limit for the expansion of low-voltage industry.

Increased operating costs have a profit-reducing effect. Some of depreciation related investment categories have unusual investment transfer, such as

The overall capital transfer rate of intelligent projects such as the ubiquitous electric power loT in various cities and cities

\begin{tabular}{|c|c|c|c|c|c|c|c|c|}
\hline \begin{tabular}{|c|} 
serial \\
number
\end{tabular} & Province & City & \begin{tabular}{|c|} 
Annual \\
investment \\
plan for \\
ubiquitous \\
electric power \\
and other \\
intelligent \\
projects
\end{tabular} & $\begin{array}{l}\text { Annual investment } \\
\text { budget for smart } \\
\text { projects such as } \\
\text { Ubiquitous Power loT }\end{array}$ & \begin{tabular}{|c|} 
Cumulative \\
investment in \\
intelligent projects \\
such as Ubiquitous \\
Power loT completed \\
\end{tabular} & $\begin{array}{c}\text { Cumulativ } \\
\text { e } \\
\text { accountin } \\
\text { g costs } \\
\text { for } \\
\text { intelligen } \\
\text { t projects } \\
\text { such as } \\
\text { Ubiquitou } \\
\text { s Power } \\
\text { loT }\end{array}$ & 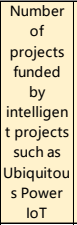 & $\begin{array}{c}\text { Capitalization } \\
\text { rate of } \\
\text { intelligent } \\
\text { projects such as } \\
\text { ubiquitous } \\
\text { power loT }\end{array}$ \\
\hline 1 & State grid Shanghai electric power company & State Grid Shanghai Electric Power Company Institute of Economics and Technology & 196 & 202 & 202 & 339 & 74 & $68 \%$ \\
\hline 2 & State grid Shanghai electric power company & State Grid Shanghai Power Company Changxing Power Supply Company & 136 & 134 & 132 & 214 & 78 & $76 \%$ \\
\hline 3 & State grid Shanghai electric power company & State Grid Shanghai Electric Power Company Qingpu Power Supply Company & 337 & 333 & 330 & 234 & 28 & $65 \%$ \\
\hline 4 & State grid Shanghai electric power company & State Grid Shanghai Electric Power Company Shinan Power Supply Company & 310 & 307 & 305 & 393 & 62 & $92 \%$ \\
\hline 5 & State grid Shanghai electric power company & Chongming Power Supply Company of State Grid Shanghai Electric Power Company & 310 & 321 & 311 & 202 & 35 & $88 \%$ \\
\hline 6 & State grid Shanghai electric power company & State Grid Shanghai Electric Power Company Fengxian Power Supply Company & 133 & 143 & 141 & 386 & 55 & $86 \%$ \\
\hline 7 & State grid Shanghai electric power company & State Grid Shanghai Electric Power Company Songjiang Power Supply Company & 356 & 353 & 359 & 188 & 10 & $75 \%$ \\
\hline 8 & State grid Shanghai electric power company & State Grid Shanghai Electric Power Company Jiading Power Supply Company & 140 & 138 & 144 & 213 & 43 & $96 \%$ \\
\hline 9 & State grid Shanghai electric power company & State Grid Shanghai Electric Power Company Maintenance Company & 159 & 154 & 153 & 384 & 24 & $72 \%$ \\
\hline 10 & State grid Shanghai electric power company & State Grid Shanghai Electric Power Company Jinshan Power Supply Company & 383 & 392 & 385 & 371 & 10 & $63 \%$ \\
\hline 11 & State grid Shanghai electric power company & State Grid Shanghai Electric Power Company Urban Power Supply Company & 203 & 207 & 205 & 116 & 60 & $76 \%$ \\
\hline 12 & State grid Shanghai electric power company & State Grid Shanghai Electric Power Company Pudong Power Supply Company & 329 & 330 & 320 & 141 & 60 & $84 \%$ \\
\hline 13 & State grid Shanghai electric power company & State Grid Shanghai Electric Power Company Shibei Power Supply Company & 143 & 146 & 144 & 206 & 70 & $98 \%$ \\
\hline
\end{tabular}

750-220kV Main Network Project investment of Nonpolicy Investment, $110 \mathrm{kV}$ and the following Urban Network Engineering Investment. The increase in operation and maintenance costs are mainly due to the high level of the Power Grid Equipment Safety Input in Production Overhaul Investment.

This article takes the abnormal situation of $110 \mathrm{kV}$ and the following Urban Network Engineering Investment transfer as an example to carry out source tracing analysis to locate problem projects and problem links. As shown in Figure 4. 


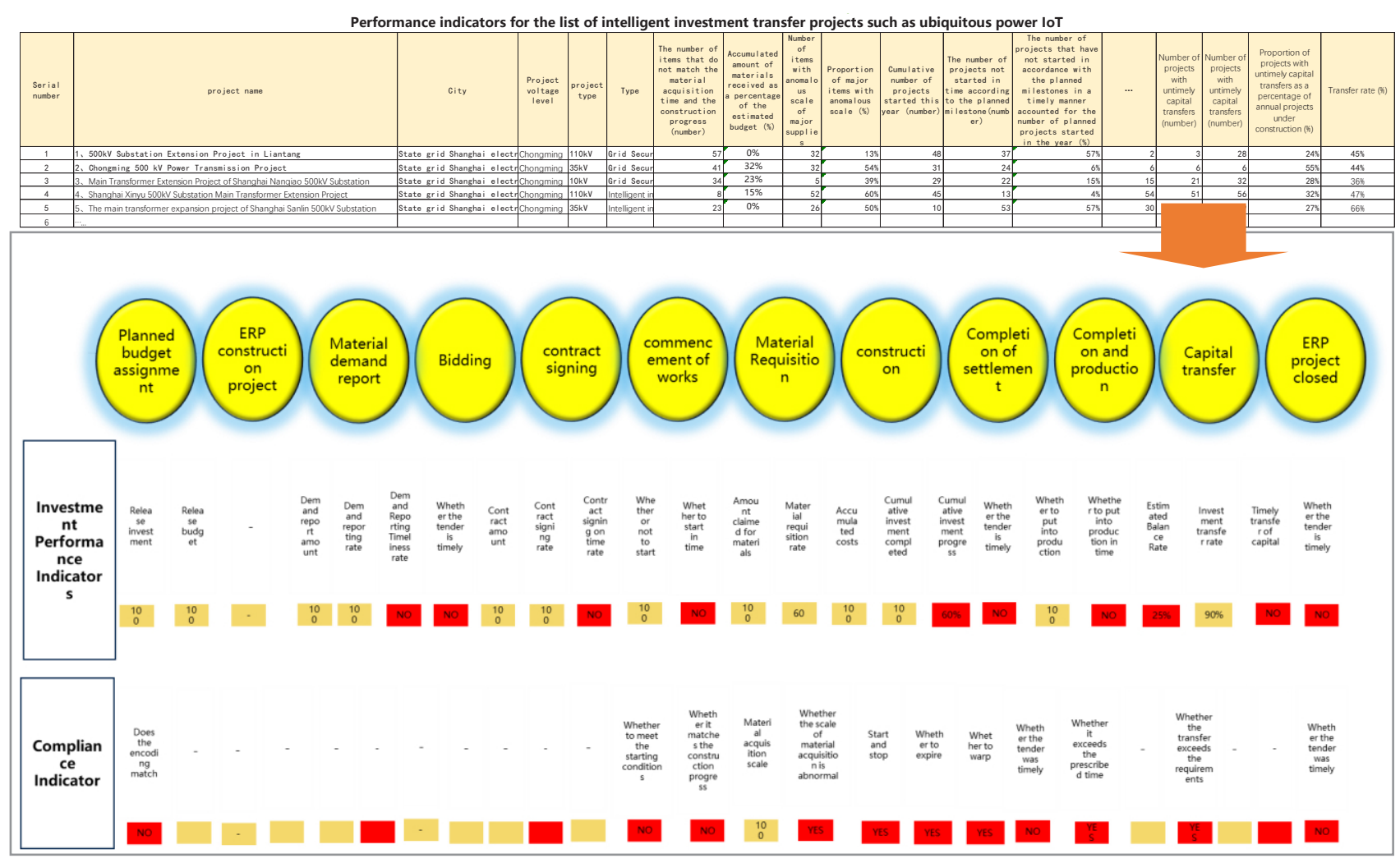

Figure 4 Example of traceability analysis of investment performance

$110 \mathrm{kV}$ and the following Urban Network Engineering Investment has 4 directions, such as Increased Supply and Expansion of Sales and Industry Expansion Supporting Investment, General Investment in Smart Investments such as the Ubiquitous Electricity Internet of Things, The Grid Security Inputs and Others. Take the Ubiquitous Electricity Internet of Things Investment as an example, we statistics on the capital transfer of such projects in various places(see table in the upper of Figure 4) and filter out a list of projects which the transfer progress is abnormal(see table in the middle of Figure 4).By penetrating into a specific project investment process, we analyze the progress of investment implementation and the rationality of investment compliance. As shown in the lower of Figure 4 , the project is in a backward situation in progresses such as material demand report, tender, contract signing, start, completion and put into operation and other aspects of the investment progress. From the point of view of compliance and reasonableness, there is a reasonable risk in the coding match, and in whether the starting conditions are matched, and in whether the construction progress is matched, and in whether the scale of material use is abnormal, and in whether start-up stops, and in whether it is overtime, and in whether it is a tail and so on.

\section{Conclusion}

This study builds a business finance fusion analysis system from the company's strategy to the strategic objective to the financial index to the business index by constructing 3 analysis models. One of the analysis models is the model of influencing factors of change of operating efficiency index, the other is a traceability analysis model of the sales of electricity and electricity price, and the last model is an investment performance traceability analysis model. These 3 models promote the precise positioning of weak links and the monitoring and analysis of the whole process of the project, and drive the economic activity analysis more systematic, more comprehensive, more real-time, more dynamic and more intelligent development. Through the use of analytical models to accurately implement pressure reduction and cost savings, strengthen the accuracy and efficiency of investment and management, the company's resource allocation efficiency has been improved, and the company's high-quality development has been promoted.

\section{References}

1. Qiaowen yang. yun liu, Application of Excel Linear Solution in Management Accounting, Business economy, 131(2018)

2. Yi zhang, Discussion on the Investment Plan Management of Power Grid Infrastructure Projects Based on Quality and Efficiency, Enterprise Reform and Management, 43(2018)

3. Yinying he, Research on the Decision-making Model of Power Supply Enterprises Based on Key Financial Indicators, North China Electric Power University, (2016)

4. Xiaojing Ding, Research on the All Progress Finance Management of Electric Power in 
Frastructure Construction Project, North China Electric Power University, (2014)

5. Tingting liu, Research on the Progress Risk Management of Infrastructure Projects of Power Grid Enterprises, North China Electric Power University, (2013) 